\title{
The alien, parthenogenetic marbled crayfish (Decapoda: Cambaridae) is entering Kis-Balaton (Hungary), one of Europe's most important wetland biotopes
}

\author{
Andor Lőkkös ${ }^{1, \star}$, Tamás Müller ${ }^{2}$, Krisztián Kovács ${ }^{3}$, Levente Várkonyi ${ }^{2}$, András Specziár ${ }^{4}$ \\ and Peer Martin ${ }^{5}$ \\ 1 Balaton Uplands National Park Directorate, Kossuth Lajos utca 16, 8229 Csopak, Hungary \\ 2 Szent István University, Institute of Aquaculture and Environmental Safety, Department of Aquaculture, Páter Károly utca 1, \\ 2100 Gödöllő, Hungary \\ 3 National Inspectorate for Environmental Protection and Nature Conservation (Northern Transdanubia), Laboratory, \\ Török Ignác utca 68., 9028 Győr, Hungary \\ ${ }^{4}$ Balaton Limnological Institute, MTA Centre for Ecological Research, Klebelsberg Kuno utca 3, 8237 Tihany, Hungary \\ ${ }^{5}$ Humboldt-Universität zu Berlin, Institut für Biologie/Vergleichende Zoologie, Philippstraße 13, 10115 Berlin, Germany
}

Received August 18, 2015 - Revised January 27, 2016 - Accepted January 28, 2016

\begin{abstract}
The marbled crayfish or Marmorkrebs, Procambarus fallax (Hagen, 1870) f. virginalis, a parthenogenetic freshwater crayfish belonging to the North American cambarids, was recorded in Hungary for the first time. Several specimens of this potentially invasive crayfish were caught at different locations in the thermal Lake Hévíz and its outflows in the western part of the country. Captured individuals covered a wide size range (5.5 to $50.5 \mathrm{~mm}$ carapace length) and one was carrying eggs and recently hatched offspring, which suggests that this organism has established a stable and self-sustaining population in the warm habitats of Lake Hévíz area. This finding is of great significance because these habitats belong to the catchment of the Danube River including Lake Balaton, and thus, a significant further spread of the marbled crayfish is likely to happen in Central Europe. Furthermore, the expansion of this crayfish already reached the Kis-Balaton, one of the landscape protection areas of the Balaton Uplands National Park, what could have currently yet unpredictable consequences for this unique wetland biotope.
\end{abstract}

Key-words: non-indigenous crayfish species / pet trade / illegal release / crayfish plague / thermal lake

Résumé - L'écrevisse marbrée, exotique, parthénogénétique (Decapoda : Cambaridae) est arrivée dans le KisBalaton (Hongrie), l'une des zones humides les plus importantes d'Europe. L'écrevisse marbrée ou Marmorkrebs, Procambarus fallax (Hagen, 1870) f. virginalis, une écrevisse parthénogénétique appartenant aux Cambaridés d'Amérique du Nord, a été rencontrée en Hongrie pour la première fois. Plusieurs spécimens de cette écrevisse potentiellement envahissante ont été capturés à différents endroits dans le lac thermal Hévíz et ses exutoires, dans la partie occidentale du pays. Les individus capturés sont d'un large éventail de tailles (de 5,5 à 50,5 mm de longueur de carapace) et l'un d'eux était porteur d'œufs et de jeunes récemment éclos, ce qui suggère que cette espèce a établi une population stable et autonome dans les habitats chauds de la région du lac Hévíz. Cette constatation est d'une grande importance parce que ces habitats appartiennent au bassin versant du Danube comprenant le lac Balaton, et donc, une propagation importante de l'écrevisse marbrée est susceptible de se produire en Europe centrale. En outre, l'expansion de cette écrevisse a déjà atteint le Kis-Balaton, l'une des zones de protection du Parc National Balaton Uplands, ce qui pourrait avoir des conséquences encore imprévisibles actuellement pour ce biotope humide unique.

Mots-clés : écrevisse non indigène / commerce d'animaux / introduction illégale / peste de l'écrevisse / lac thermal

\section{Introduction}

Freshwater crayfish have, inter alia because of their large size, omnivorous diet, and burrowing activities, a fundamen-

\footnotetext{
* Corresponding author: a.lokkos@gmail.com
}

tal impact on freshwater ecosystems. Thus, the occurrence or disappearance of a crayfish species or their replacement by an ecologically different species may permanently disturb the natural balance in the affected waters (Nyström, 2002; Kouba et al., 2014). In Europe, the crayfish fauna have undergone 
massive changes since the middle of the 19th century due not only to water pollution and habitat destruction as a result of the ongoing industrialisation, but also by the introduction of North American crayfish species (Holdich et al., 2009). In addition, the crayfish plague Aphanomyces astaci Schikora 1906, which is a highly contagious disease carried and transmitted by the largely resistant introduced North American crayfish species, causes mass mortalities in European indigenous crayfish populations (Oidtmann et al., 1999). Consequently, in large parts of Europe, either crayfishes have been completely eradicated or indigenous crayfish species (ICS) have been replaced by their non-indigenous competitors (NICS). In the past, fishery exploitation was the primary motivation for introducing NICS to European inland waters, but the aquarium trade is becoming a serious source of introductions (Schulz et al., 2009). Because keeping ornamental freshwater crayfish has come into fashion during recent years, the risk that North American species are released into the wild has increased alarmingly. Eleven NICS were already recorded in Europe to date, and most of them are well established (Chucholl, 2013; Kouba et al., 2014).

One of the NICS is marbled crayfish (in German: Marmorkrebs) Procambarus fallax (Hagen, 1870) f. virginalis (Martin et al., 2010) which was discovered for the first time in the German aquarium trade in the midnineties of the last century (Lukhaup, 2001). Although its geographic origin and natural distribution is still unknown, Martin et al. (2010) identified this crayfish as the parthenogenetic form of the cambarid slough crayfish $P$. (Ortmannicus) fallax (Hagen, 1870), which has its natural range throughout Florida and in southern Georgia (Hobbs, 1989). Marbled crayfish attract particular attention because it is the only obligate parthenogenetic decapod known to date (Scholtz et al., 2003) which produces genetically uniform progeny (Martin et al., 2007; Vogt et al., 2008) and is a triploid organism (Martin et al., 2016). Because of this unusual reproduction mode, marbled crayfish is not only an interesting research object for a variety of scientific disciplines but also represents a menace as potential invader since a single individual once released from aquaria into the wild might be able to found a new population (Marten et al., 2004; Faulkes, 2010). Indeed, marbled crayfish rapidly established populations in Madagascar, threatening the endemic freshwater biodiversity (Jones et al., 2009; Kawai et al., 2009). However, even in Europe, where the warm adapted crayfish encounters rather less favourable climatic conditions, several human-mediated occurrences in the wild have been recorded in five countries (latest updated summary is given in Chucholl (2014)). The principal cause for this success in the latter case is the wide distribution of marbled crayfish in European aquaria, which increases the risk of illegal releases into nature (Chucholl, 2013). Thus, it is certain that the number of affected countries will continue to increase.

In Hungary, three ICS are known to occur: the noble crayfish Astacus astacus (Linnaeus, 1758), the narrowclawed crayfish Astacus leptodactylus Eschscholz, 1823, and stone crayfish Austropotamobius torrentium (Schrank, 1803) (Thuránszky and Forró, 1987). Despite the depletion of the population by water pollution and crayfish plague, A. astacus is found in the entire country, whereby it is more common in western and northern territories. Astacus leptodactylus, however, is less widespread and more restricted to lowland waters. Austropotamobius torrentium is the rarest ICS in the country and only occurs in few mountain streams in the western and northern part of the territory (Puky et al., 2005). Apart from these native species, two North American NICS are also established in Hungary. The spiny-cheek crayfish Orconectes limosus (Rafinesque, 1817) was introduced from Germany at the end of the 1950s (Thuránszky and Forró, 1987; Puky and Schád, 2006) and has rapidly spread in the Danube catchment area since the middle of the 1980s (Holdich, 2002; Puky and Schád, 2006). The second NICS is the signal crayfish Pacifastacus leniusculus (Dana, 1852) which may have immigrated to North West Hungary around 2000 from Austria, where this species was introduced in the 1970s (Illés, 2002; Kovács et al., 2005). In addition to these two established NICS, a further North American species, the red swamp crayfish Procambarus clarkii (Girard, 1852), was recently recorded for the first time in a thermal lake near the Hungarian capital of Budapest (Weiperth et al., 2015) and thus, it can be assumed that this NICS will be established in the country too.

Kis-Balaton (English: Little Balaton), comprising the Lake Hídvégi and the largely reedy Lake Fenéki, is one of the greatest and most important marshland biotopes in Europe. Because of its uniqueness, about $150 \mathrm{~km}^{2}$ of Kis-Balaton and its surrounds are strictly protected as part of the Balaton Uplands National Park by the Habitats Directive of the European Union (Natura 2000) (Government of Hungary, 2004) and by the Ramsar Convention, which included this area in its "List of Wetlands of International Importance" (Ramsar Convention Secretariat, 2015). Kis-Balaton drains into the River Zala, the most important inflow of the adjacent Lake Balaton, which is the largest lake in Central Europe $\left(596 \mathrm{~km}^{2}\right)$. In the past, KisBalaton was part of Lake Balaton. However, due to human interventions, such as the extension of the only outflow Sió Canal in the 18th century, the water level of Lake Balaton decreased significantly, leading to drainage of large parts of the Kis-Balaton. Consequently, Kis-Balaton became separated and lost its function as nutrient sink. Thus, River Zala could get to the Lake Balaton without any preliminary reduction of its pollution load, resulting in a dramatic increase of eutrophication. To reverse this process, various ecological restoration measures have been implemented to rewet the Kis-Balaton since the 1980s, which improved the water quality of Lake Balaton, and it is currently is regarded as excellent.

In this study, we report the first record of the marbled crayfish in Hungary, describe the unique situation which this crayfish encounters in the newly occupied habitats, and discuss its possible ecological impact on the Balaton Uplands National Park and its further spreading potential in the region.

\section{Material and methods}

\subsection{Study sites}

All study sites, including Lake Hévíz, its outflow Északiárapasztó-csatorna, and the canals Páhoki-övcsatorna and Egyesített-övcsatorna (Figure 1), belong to the catchment area 


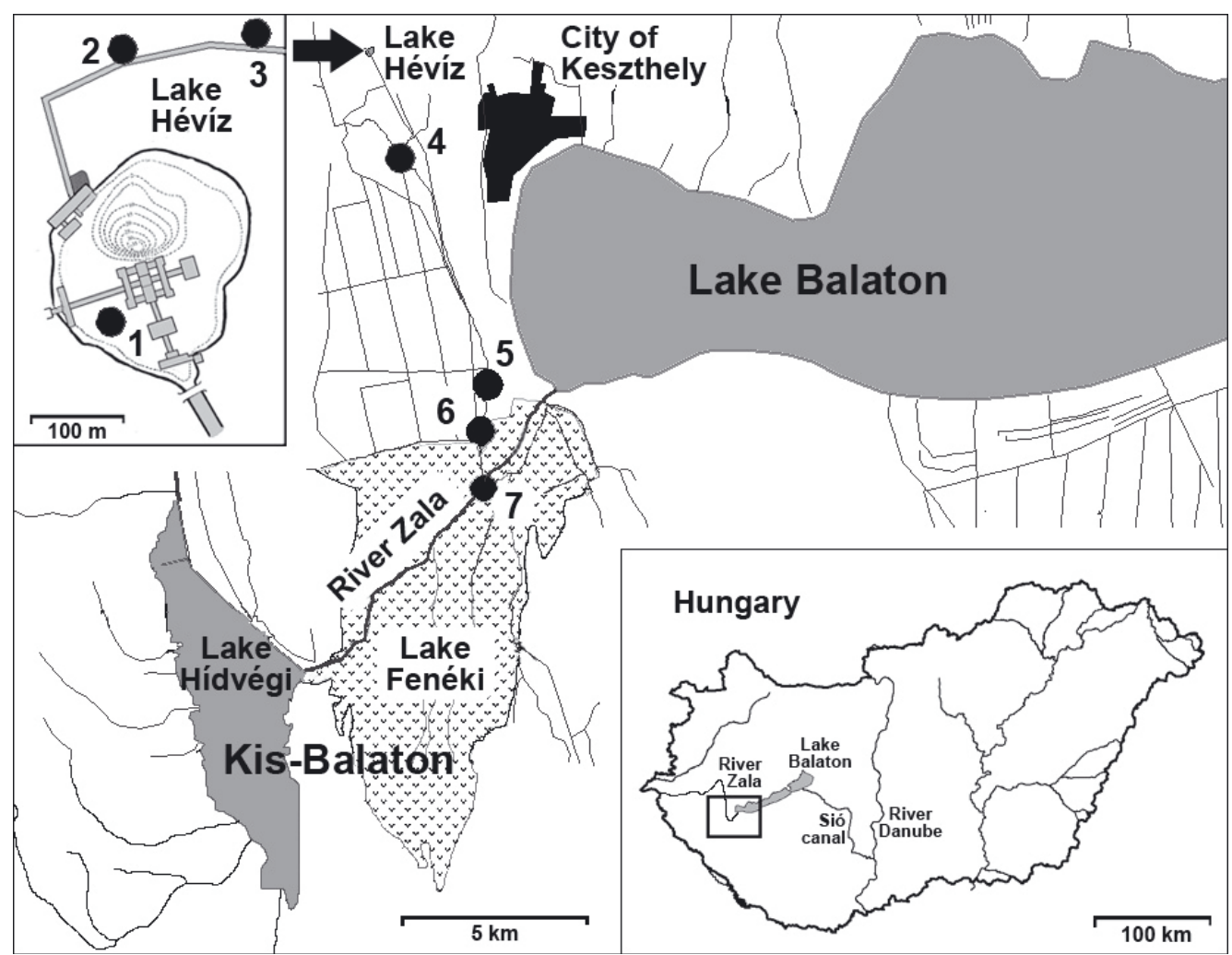

Fig. 1. Records of marbled crayfish (black filled circles marked with numbers) in the West-Balaton region (Hungary). (1): Lake Hévíz; (2) and (3): Északi-árapasztó-csatorna; (4): Páhoki-övcsatorna; (5)-(7): Egyesített-övcsatorna. The large map represents the described study area in the West-Balaton region whose geographic position within Hungary is shown as a rectangle on the smaller map (bottom right). The small map (top left) is an enlarged section of thermal Lake Hévíz whose position on the large map is indicated by the black arrow. The geometric shapes within the lake represent the outlines of the bathing buildings, and the dashed concentric lines are the depths contours of the water.

of the Lake Balaton and are part of the drainage basin of the Danube River.

Lake Hévíz is located $5.5 \mathrm{~km}$ northwest from Lake Balaton (Figure 1, site 1; Figure 2, bottom; Figure 3) and is the biggest natural thermal lake in the world. It has been used as a spa continuously since the second century and even today, the appearance of the lake is characterized by dominant bathing buildings (Figure 1, small map in the top left). It has a surface area of 4.44 ha and a mean depth of $1.5-1.8 \mathrm{~m}$ with a maximum depth at $38.5 \mathrm{~m}$. The lake is fed by moderate temperature $\left(26^{\circ} \mathrm{C}\right)$ and hot $\left(41^{\circ} \mathrm{C}\right)$ springs, which are located in a cave at the deepest part of the lake. The total discharge is about 390 L.s ${ }^{-1}$, resulting in a very short, 3.5 days water retention time in the lake. The water temperature of Lake Hévíz varies between $22{ }^{\circ} \mathrm{C}$ during the winter and $38^{\circ} \mathrm{C}$ in the summer in contrast to the typical $11-12{ }^{\circ} \mathrm{C}$ mean annual water temperature of other waters in the region (Figure 3 ). It has calcium and magnesium hydrogen carbonated water with a unique chemical composition and a relatively low concentration of dissolved oxygen (Table 1). There is a major (Hévíz-lefolyó) and a minor (Északi-árapasztó-csatorna) outflow, which both flow via several other canals into River Zala (Specziár, 2004). Due to its warm water year round, Lake Hévíz has been a preferred location for experimental and illegal release of exotic species. For example, several subtropical and tropical plant species have been introduced in Lake Hévíz and its thermal outflows including the India red water-lily Nymphaea rubra var. longi- flora Lovassy 1908, which cover a large part of the lake in summer (Szabó, 1998, 2002). Several non-indigenous fishes have been introduced. The eastern mosquitofish Gambusia holbrooki Girard 1859 was introduced by authorities around the year 1940 to reduce (unsuccessfully) the mosquito population. Other established species include the rainbow cichlid Archocentrus multispinosus (Günther 1867), the pumpkinseed sunfish Lepomis gibbosus (Linneaus 1758), and the recently recorded jew el cichlid Hemichromis guttatus Günther 1862, all of which are thought to have been released by aquarium hobbyists (Bíró, 1997; Ponyi, 2002; Harka and Sallai, 2004; Specziár, 2004; Harka et al., 2014).

The Páhoki-övcsatorna (Figure 1, site 4) is a one metre deep and four meter wide slowly flowing canal south of Lake Hévíz which flows through the canal Déli-keresztcsatorna into the canal Egyesített-övcsatorna. The water, whose temperature never drops below the freezing point even in cold winters, has a dense submerged vegetation and muddy substrate. The Egyesített-övcsatorna (Figure 1, sites 5, 6. and 7) is situated a few kilometres west of Lake Balaton and is formed by the confluence of the stream Gyöngyös-patak and the canal Hévíz lefolyó, the southern and most important outflow of Lake Hévíz. The canal is a slowly flowing and densely vegetated water body which flows into the River Zala. The canal is characterized by muddy substrate and has a depth of two metres and a width of five metres. On its final three kilometres, Egyesített-övcsatorna is part of the Balaton Uplands National 


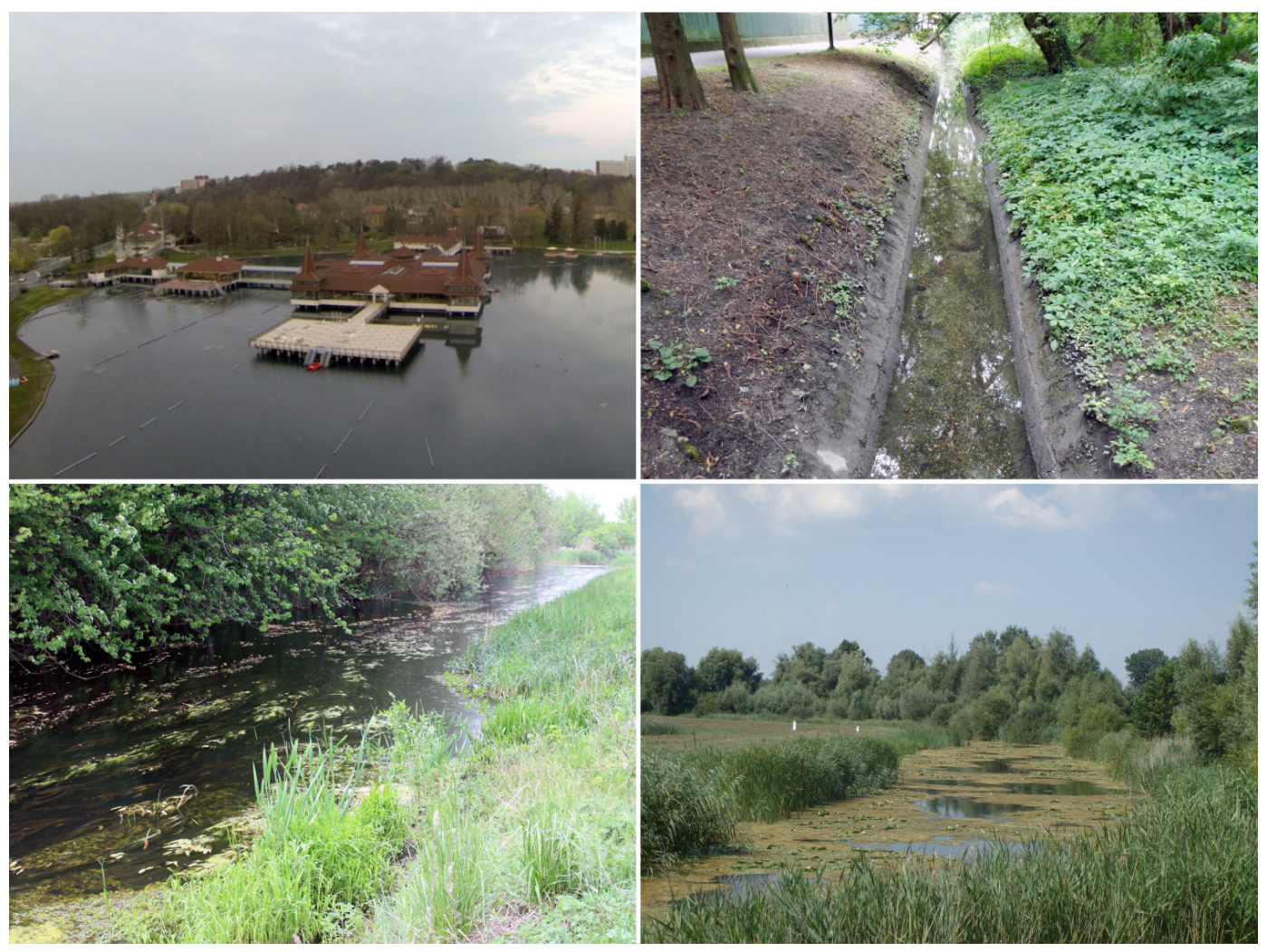

Fig. 2. Locations of marbled crayfish records presented in this study: Lake Hévíz (site (1), top left); Északi-árapasztó-csatorna (sites (2) and (3), top right (image courtesy of Róbert Vidéki)); Páhoki-övcsatorna (site (4), bottom left); Egyesített-övcsatorna (sites (5)-(7), bottom right).

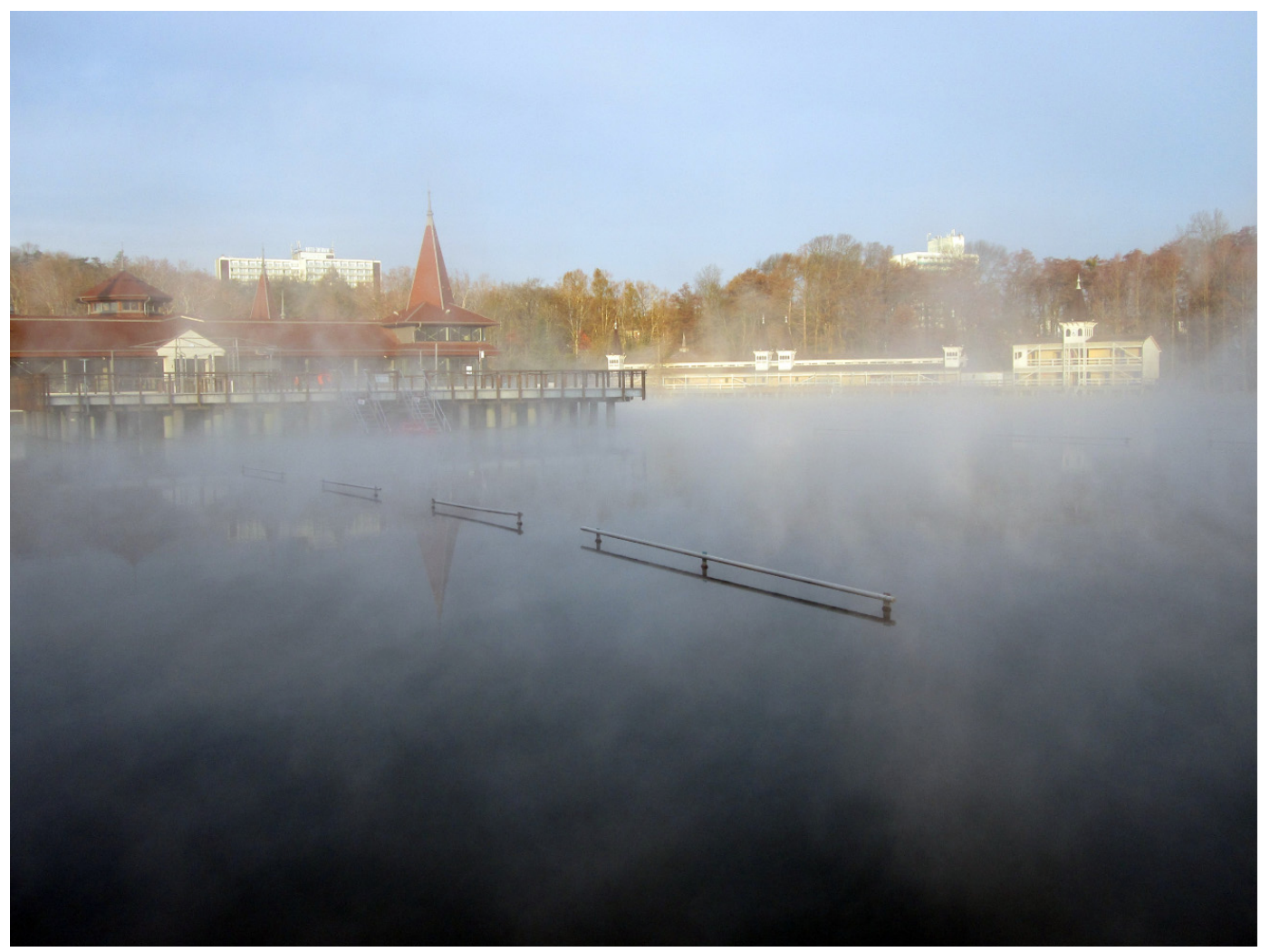

Fig. 3. A typical phenomenon of the marbled crayfish location Lake Hévíz in the cold season: Fog above the water surface on a morning in early spring showing the drastic temperature difference between the thermal lake and its ambient air. 
Table 1. Water quality parameters of Lake Hévíz measured at two different depths. Values of parameters marked with asterisk are rounded averages with standard deviation of measurements taken from five different sampling points across the lake.

\begin{tabular}{|c|c|c|}
\hline Water depth & $0.1 \mathrm{~m}$ & $1.2 \mathrm{~m}$ \\
\hline Temperature $\left[{ }^{\circ} \mathbf{C}\right]^{*}$ & $27.7 \pm 0.3$ & $28.2 \pm 0.2$ \\
\hline Dissolved oxygen $\left[\mathrm{mg} \cdot \mathrm{L}^{-1}\right]^{*}$ & $2.6 \pm 0.1$ & $2.4 \pm 0.1$ \\
\hline Oxygen saturation [\%]* & $33 \pm 1.0$ & $31 \pm 1.1$ \\
\hline Conductivity $\left[\mu \mathrm{S} \cdot \mathrm{cm}^{-1}\right]^{*}$ & $769 \pm 4$ & $759 \pm 2$ \\
\hline pH & 7.3 & 7.4 \\
\hline $\mathrm{POC}\left[\mathrm{mg} \cdot \mathrm{L}^{-1}\right]$ & $<20$ & $<20$ \\
\hline $\mathrm{SO}_{4}^{2-}\left[\mathrm{mg} \cdot \mathrm{L}^{-1}\right]$ & 65 & 71 \\
\hline $\mathrm{Fe}\left[\mathrm{mg} \cdot \mathrm{L}^{-1}\right]$ & $<0.04$ & $<0.04$ \\
\hline $\mathrm{NO}_{3}^{-}\left[\mathrm{mg} \cdot \mathrm{L}^{-1}\right]$ & $<0.3$ & $<0.3$ \\
\hline $\mathrm{NH}_{4}^{3} \mathrm{~N}\left[\mathrm{mg} \cdot \mathrm{L}^{-1}\right]$ & $<0.2$ & $<0.2$ \\
\hline $\mathrm{S}^{2-}\left[\mathrm{mg} \cdot \mathrm{L}^{-1}\right]$ & $<0.05$ & $<0.05$ \\
\hline $\mathbf{F}^{-}\left[\mathrm{mg} \cdot \mathrm{L}^{-1}\right]$ & $<0.1$ & $<0.1$ \\
\hline $\mathrm{NO}_{2} \mathrm{~N}\left[\mathrm{mg} \cdot \mathrm{L}^{-1}\right]$ & $<0.03$ & $<0.03$ \\
\hline Total hardness $\left[{ }^{\circ} \mathbf{d}\right]$ & 16.5 & 16.5 \\
\hline Residual hardness $\left[{ }^{\circ} \mathbf{d}\right]$ & 0.61 & 0.61 \\
\hline
\end{tabular}

Park (Figure 1, sites 6 and 7). The Északi-árapasztó-csatorna (Figure 1, sites 2 and 3) is a half a metre deep and one metre wide concrete open air channel which drains Lake Hévíz to the north. All study sites, including their coordinates, are summarized in Table 2. Since all three water bodies are fed by warm water from Lake Hévíz, their water temperatures are considerably higher than other waters in the region.

\subsection{Sampling}

All first records of marbled crayfish at each study site were coincidental findings during routine surveys of the ecological status of the respective water performed by different coauthors. The samplings took sporadically place in a period from July 2013 to November 2014 (detailed dates are given in Figure 1).

In Lake Hévíz, marbled crayfish were first caught by means of a benthic multi-mesh gillnet for sampling of fish with a length of $2.5 \mathrm{~m}$ and a height of $1.5 \mathrm{~m}$ high, and 12 mesh sizes ranging from 5 to $55 \mathrm{~mm}$ (European Standard, EN 14757:2005) which is routinely applied for monitoring of fish populations. A follow-up examination at the same area was carried out in the night from 14th to 15th November 2014 by placing single "Pirate" crayfish traps (Bock-Ås Ltd., Finland) baited with cyprinid fish pieces at 12 different locations distributed along the whole shore line over a period of three hours. At all other sites, marbled crayfish were caught by sweeping a dip or long-handled pond net just above the substrate and among the submerged vegetation as usually performed at routine survey of macrozoobenthos. To estimate the reproductive capacity of the detected population, the carapace length of each captured specimen was measured (except of those from sites 6 and 7). For molecular analysis, some of the caught individuals were preserved in in $96 \%$ ethanol.

Because of the particular characteristics of Lake Hévíz, we monitored its temperature, dissolved oxygen content, and conductivity at five sampling points in the surface and bottom water layers between 4.30-5.10 a.m. by a dual-input portable multimeter HQ40d (Hach Lange GmbH, Germany). Other water quality parameters of Lake Hévíz were determined at one site on its eastern shore by a compact photometer PF-12 NANOCOLOR ${ }^{\circledR}$ tube tests at sampling point (MACHEREYNAGEL GmbH \& Co. KG, Germany). A summary of all measured parameters is shown in Table 1 .

\subsection{Molecular analysis}

To confirm the preliminary identification of the caught crayfish as marbled crayfish by using morphological characters, we analysed some non-identifiable specimens genetically. We used partial sequences of the mitochondrial protein coding cytochrome oxidase subunit I gene (COI), the standard barcode region used for higher animal groups (Hebert et al., 2003), and the mitochondrial $12 \mathrm{~S}$ ribosomal RNA gene, which was already applied for identifying the taxonomic position of marbled crayfish (Martin et al., 2010). The analyses were performed according the protocol described in Martin et al. (2010), using the standard universal primer pair LCO1490/HCO2198 designed by Folmer et al. (1994) for amplifying the COI fragment and the primers CF12FOR and CF12REV designed by Braband et al. (2007) for the $12 \mathrm{~S}$ rRNA gene respectively. The sequencing of the fragments was performed by the service company LGC Genomics Berlin, Germany. Obtained datasets of both forward and reverse strands of the COI and $12 \mathrm{~S}$ fragments were aligned using the ClustalW Multiple alignment application (Thompson et al., 1994) integrated in the program BioEdit version 7.0.9.0. for Windows (Ibis Biosciences, USA; Hall 1999). Finally, the resulting sequences were manually trimmed by removing the remaining parts of the primer regions.

\section{Results and discussion}

The molecular analysis revealed that the examined crayfish have completely identical sequences of both COI and $12 \mathrm{~S}$ fragments, as already found in marbled crayfish in earlier studies (e.g. Martin et al. (2010), GenBank ${ }^{\circledR}$ accession numbers: HM358010, HM358014). This result corresponds with our previous preliminary identification, based on morphological characteristics, which indicate that the freshwater crayfish caught in Lake Hévíz and its tributaries were marbled crayfish. This is the first record of P. fallax. f. virginalis in natural waters in Hungary.

The first marbled crayfish was caught by happenstance in the canal Páhoki-övcsatorna during a survey of macrozoobenthos on 31 July 2013 (Figure 1: Site 4.). Further captures took place in Lake Hévíz during a fish monitoring on 27 March 2014 (Figure 1: Site 1.), the canal Egyesített-övcsatorna on 22 May 2014 (Figure 1: Site 5., 6. and 7.), and the canal Északiárapasztó-csatorna on 5 June 2014 (Figure 1: Site 2. and 3.) (in the latter two also during a survey of macrozoobenthos). Additionally, follow-up examinations for confirming the occurrence of marbled crayfish were performed at all four waters (Table 2). Altogether 42 specimens of marbled crayfish were captured in the study period: sixteen individuals from Lake Hévíz 
Table 2. Summarised data of marbled crayfish records in the West-Balaton region (Hungary).

\begin{tabular}{|l|c|c|c|c|c|}
\hline No & Site & Coordinates & Date & $\begin{array}{c}\text { No of caught } \\
\text { crayfish }\end{array}$ & $\begin{array}{c}\text { Range of carapace } \\
\text { length }(\mathrm{mm})\end{array}$ \\
\hline $\mathbf{1 .}$ & Lake Hévíz & $\mathrm{N} 46^{\circ} 78.754^{\prime}, \mathrm{E} 17^{\circ} 19.168^{\prime}$ & 27.03 .2014 & 2 & $38.2-41.2$ \\
& & & 14.11 .2014 & 14 & $36.4-50.5$ \\
\hline $\mathbf{2 .}$ & Északi-árapasztó-csatorna & $\mathrm{N} 46^{\circ} 47.331^{\prime}, \mathrm{E} 17^{\circ} 11.549^{\prime}$ & 05.07 .2014 & 2 & - \\
\hline $\mathbf{3 .}$ & Északi-árapasztó-csatorna & $\mathrm{N} 46^{\circ} 47.344^{\prime}, \mathrm{E} 17^{\circ} 11.665^{\prime}$ & 05.07 .2014 & 1 (dead) & - \\
\hline $\mathbf{4 .}$ & Páhoki-övcsatorna & $\mathrm{N} 46^{\circ} 45.588^{\prime}, \mathrm{E} 17^{\circ} 12.290^{\prime}$ & 31.07 .2013 & 1 & $5.0-28.0$ \\
& & & 24.07 .2014 & 8 & \\
\hline $\mathbf{5 .}$ & Egyesített-övcsatorna & $\mathrm{N} 46^{\circ} 42.538^{\prime}, \mathrm{E} 17^{\circ} 14.258^{\prime}$ & 26.05 .2014 & 7 & $10.0-31.5$ \\
\hline $\mathbf{6 .}$ & Egyesített-övcsatorna & $\mathrm{N} 46^{\circ} 40.837^{\prime}, \mathrm{E} 17^{\circ} 14.199^{\prime}$ & 22.05 .2014 & 2 & $34.0-34.5$ \\
\hline $\mathbf{7 .}$ & Egyesített-övcsatorna & $\mathrm{N} 46^{\circ} 41.523^{\prime}, \mathrm{E} 17^{\circ} 14.263^{\prime}$ & 28.07 .2014 & 5 & $6.5-19.0$ \\
\hline
\end{tabular}

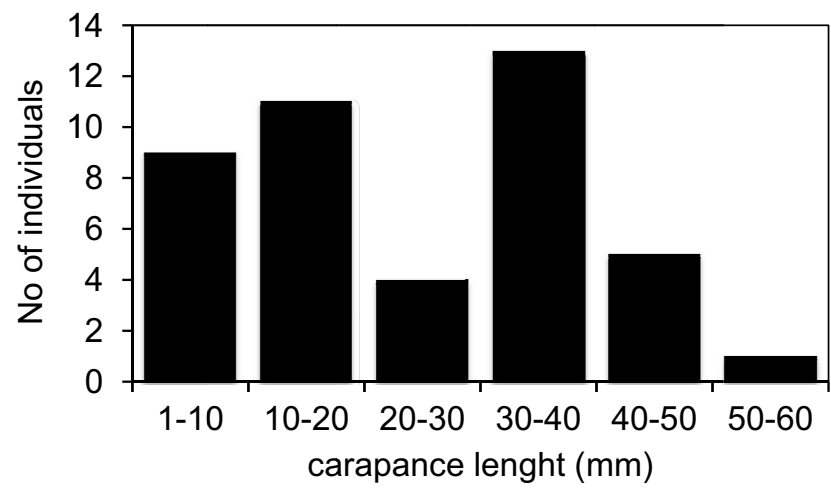

Fig. 4. All Marbled crayfish individuals captured in the study area $(n=39)$ sorted by carapace length (each diamond corresponds to one specimen).

with carapace lengths (CL) ranging from 36.4 to $50.5 \mathrm{~mm}$, nine individual from the canal Páhoki-övcsatorna with CL from 5.0 to $28.0 \mathrm{~mm}$, fourteen from the canal Egyesített-övcsatorna with CL from 6.5 to $34.5 \mathrm{~mm}$, and three specimens from the canal Északi-árapasztó-csatorna (CL not measured) (Table 2). The relatively large number of specimens of different sizes (total range: CL 5.0 to $50.5 \mathrm{~mm}$, see Figure 4), one of which was carrying both eggs and recently hatched offspring, combined with the recapture of eight individuals in the canal Páhokiövcsatorna after one year, using methods used were not specially intended for crayfish captures on a small number of sampling dates strongly suggest that the population in the region is stable and self-sustaining.

As described above, Lake Hévíz and its outlets is a preferred site for illegal introductions by aquarium hobbyists and thus, it is very likely that marbled crayfish get into the wild in the same way. To estimate the risk of further releases, we interviewed the only three official pet storeowners within an area $20 \mathrm{~km}$ around of the study site. The sellers in Hévíz and Keszthely informed us that marbled crayfish, although provided in the past, are not available today. This might be because marbled crayfish have become easily available on the Internet for one dollar or less, sometimes even for free (web research by the authors, see also below). According to store owners, the trade for pets has become less profitable, a trend we have also seen in Germany. However, even if marbled crayfish appears to have been gradually removed from the retail trade (at least in the mentioned two countries), it is still easily avail- able online. For example, even a simple internet research by means of a common search engine (https://www.google.hu/) using the Hungarian term "márványrák eladó" (English: marbled crayfish for sale) led to a large number of results mainly offered by non-commercial providers from all over the country (queried 17 September 2014). Consequently, marbled crayfish is still widespread in the uncontrollable 'grey market' and so we have to anticipate that there are likely to be further releases of this ornamental crayfish in the wild in Hungary. Detailed studies about the relationship between the trade with marbled crayfish and the risk of their release as well as the prediction of their successful establishment in the wild are given in Feria and Faulkes (2011), Chucholl (2013, 2014), Patoka et al., (2014) and Lipták and Vitázková, (2015) .

The described occurrence of marbled crayfish in Hungary has some characteristics which differ remarkably from other ones in the European continent. Since marbled crayfish have reached the Kis-Balaton via the canal Egyesített-övcsatorna, this is the first time that a category II type of strictly protected area (according to the definition of the International Union for Conservation of Nature (IUCN)) has been directly affected by this crayfish in Europe. Apart from the fact that introduced alien species are generally unwelcome as adulterating elements in national parks that were founded to conserve regional ecosystems of great significance, marbled crayfish could also have an immediate negative impact on the sensible natural balance of this unique marshland biotope. Since freshwater crayfish have not occurred in the area for more than a half century (Puky et al., 2005), a sudden abundant appearance of such a keystone taxon might dramatically change the diversity and structure of the food web of the area. For example, crayfish can be effective grazers on the water vegetation (e.g. Carpenter and Lodge, 1986; Feminella and Resh, 1989; Nyström, 1999; van der Wal et al., 2013) and thus, a high marbled crayfish density could lead to a significant decline of submerged macrophytes and therefore to an increasing of the nutrient load. This, in turn, would reverse the above-described positive effect of the ecological restoration of Kis-Balaton, which has made the wetland to a retention basin of nutrients from River Zala, leading to the current good water quality of the adjoining Lake Balaton. Also, direct negative effects of crayfish by predation on the macrozoobenthos fauna and amphibians are well documented (Nyström et al., 2001; Moorhouse et al., 2014), whereas their influence on fishes is rather indirect by reduction of macrophytes which serve the vertebrates as breeding sites 
and shelter. On the other hand, crayfishes are an important transformer of energy to higher trophic level which can also result in a positive effect on predatory fishes. Detailed reviews of the complex role of crayfish in freshwater ecosystems is given by Nyström (2002) and Reynolds and Souty-Grosset (2012). The biggest impact through introduced crayfish, however, is on the autochthonous crayfish fauna, as shown in Europe, where ICS have been replaced by North American species in large parts of the continent. At first sight, this effect does not seem to be of great importance in the area affected by marbled crayfish since autochthonous crayfish species have become extinct in Lake Balaton and the lower stretch of its inflowing River Zala in the 1960s due to crayfish plague and the introduction of the European eel Anguilla anguilla Linnaeus 1758 (Padisák, 1999; Puky et al., 2005). However, future projects for the reintroduction of ICS such as started in the Balaton Uplands National Park at the early 1990s (Puky et al., 2005) could fail in areas already settled with marbled crayfish because of its capability to transmit the crayfish plague (Keller et al., 2014) what would lead to the immediately death of the just resettled native crayfishes.

A further special feature of this Hungarian occurrence of marbled crayfish is the thermal Lake Hévíz, which increases considerably the risk of a long-term establishment of this alien crayfish in the region. As described above, marbled crayfish is, like its sexual ancestors from Florida, adapted to a warmer, subtropical climate and so a sufficiently high water temperature is a crucial factor for its survival in the wild. For example, marbled crayfish requires for an optimal growth and reproduction water temperatures above $20{ }^{\circ} \mathrm{C}$ and breeding completely stops at temperatures below $15^{\circ} \mathrm{C}$ (Seitz et al., 2005), but marbled crayfish might be able to withstand low winter temperatures in the European temperate zone (Kaldre et al., 2016, Veselý et al., 2015). In the West-Balaton region, however, the thermal Lake Hévíz provides marbled crayfish all year round water temperatures above $20^{\circ} \mathrm{C}$ and, because of the large discharge of the lake, its outflows are distinctly warmer than other waters in the surrounding area (Szabó, 1998). Consequently, even if marbled crayfish would be largely extinguished in the region during a harsh winter, the individuals in Lake Hévíz and its outlets could survive and would be able to recover the population within a short period, not the least due to their asexual reproduction mode. Thus, we fear that this alien crayfish will become an integral part of the fauna of the West-Balaton region.

Moreover, as shown by site 7 in Figure 1, marbled crayfish has already appeared in the place where the canal Egyesítettövcsatorna flows into the River Zala. Since the Zala estuary to Lake Balaton is only less than five kilometres away from this location, it can be assumed that the arrival of marbled crayfish in Central Europe's largest lake is imminent or has already occurred. However, whether this alien crayfish is able to found a stable population in Lake Balaton will depend on its capacity to adapt to the fluctuating living condition in that water caused by the prevailing continental climate in this region with warm summers and cold winters. Due to its shallow depth of an average of $3.3 \mathrm{~m}$, Lake Balaton is subject to strong seasonal fluctuations on the water temperature, which annually ranges from near the freezing point in winter to almost $30{ }^{\circ} \mathrm{C}$ in summer.
Further, the lake is usually ice-covered for about 30 to 60 days between December and February (Vörös et al., 2009). Consequently, while marbled crayfish on the one hand would find optimal living conditions in summer for three to four months, it would be faced on the other hand by a quite long harsh period in the colder season of the year. Thus, establishment and further development of a marbled crayfish population in Lake Balaton, which is currently settled neither by a native nor by another alien crayfish species, will be dependent on its capability to compensate the potential losses in winter during the short summer period in which reproduction is only possible.

In conclusion, marbled crayfish seems to be established in the region but it is difficult to foresee in which way and to what extent the ecosystem of the landscape protection area Kis-Balaton will be affected by this, and how this alien crayfish will continue to spread. The question arises as to what measures could be taken at this early stage of colonisation to eradicate this introduced crustacean or, at least, to control its expansion. Unfortunately, all proposed methods such as manual removal by netting, trapping, or electrofishing, physical habitat alterations, stocking of predators, and application of biocides, chemicals, or microbial pathogens (Freeman et al., 2010) are either incompatible with the legal regulations for national parks, or are impractical due to the vastness of the affected area. However, we should make the most of this situation and keep a close eye on the further development of the occurrence in the West-Balaton region since this could enable us to gain new insights from the largely unknown interaction between marbled crayfish and European freshwater ecosystems.

Acknowledgements. We would especially like to thank Róbert Vidéki for providing the data of marbled crayfish records in the Északi-árapasztó-csatorna. The City Council and the Spa Hévíz \& Saint Andrew Hospital for Rheumatic Diseases is gratefully acknowledged for granting permission to survey Lake Hévíz. Tamás Müller received a Bolyai János Research Grant by the Hungarian Academy of Sciences (BO_26/11/4). Last but not least, we are very grateful to Zen Faulkes for improving the English and for his valuable comments on the manuscript.

\section{References}

Bíró P., 1997. Temporal variation in Lake Balaton and its fish populations. Ecol. Freshw. Fish., 6, 196-216.

Braband A., Kawai T. and Scholtz G., 2007. The phylogenetic position of the East Asian freshwater crayfish Cambaroides within the Northern Hemisphere Astacoidea (Crustacea, Decapoda, Astacida) based on molecular data. J. Zool. Syst. Evol. Res., 44, $17-24$.

Carpenter S.R. and Lodge D.M., 1986. Effects of submersed macrophytes on ecosystem processes. Aquat. Bot., 26, 341-370.

Chucholl C., 2013. Invaders for sale: trade and determinants of introduction of ornamental freshwater crayfish. Biol. Invasions, 15, 125-141.

Chucholl C., 2014. Predicting the risk of introduction and establishment of an exotic aquarium animal in Europe: insights from one decade of Marmorkrebs (Crustacea, Astacida, Cambaridae) releases. Manag. Biol. Invasion., 5, 309-318. 
Faulkes Z., 2010. The spread of the parthenogenetic marbled crayfish, Marmorkrebs (Procambarus sp.), in the North American pet trade. Aquat. Invasions, 5, 447-450.

Feminella J.W. and Resh V.H., 1989. Submersed macrophytes and grazing crayfish: an experimental study of herbivory in a California freshwater marsh. Holarct. Ecol., 12, 1-8.

Feria T.P. and Faulkes Z., 2011. Forecasting the distribution of Marmorkrebs, a parthenogenetic crayfish with high invasive potential, in Madagascar, Europe, and North America. Aquat. Invasions, 6, 55-67.

Folmer O., Black M., Hoeh W., Lutz R. and Vrijenhoek R., 1994. DNA primers for amplification of mitochondrial cytochrome $\mathrm{c}$ oxidase subunit I from diverse metazoan invertebrates. Mol. Mar. Biol. Biotechnol., 3, 294-299.

Freeman M.A., Turnbull J.F., Yeomans W.E. and Bean C.W., 2010. Prospects for management strategies of invasive crayfish populations with an emphasis on biological control. Aquat. Conserv., 20, 211-223.

Government of Hungary, 2004. 275/2004. (X. 8.) Kormányrendelet az európai közösségi jelentôségú természetvédelmi rendeltetésú területekröl. Magyar Közlöny, 143, 11756-11817.

Hall T.A., 1999. BioEdit: a user-friendly biological sequence alignment editor and analysis program for Windows 95/98/NT. Nucleic Acids Symp. Ser., 41, 95-98.

Harka Á. and Sallai Z., 2004. Magyarország halfaunája. Képes határozó és elterjedési tájékoztató. Nimfea Természetvédelmi Egyesület, Szarvas, 269 p.

Harka Á., Nyeste K., Nagy L. and Erös T., 2014. Jewel cichlids (Hemichromis guttatus Günther, 1862) in thermal water of Lake Hévíz (Western Hungary). Pisces Hungarici, 8, 29-34.

Hebert P.D.N., Cywinska A., Ball S.L. and deWaard J.R., 2003. Biological identifications through DNA barcodes. Proc. R. Soc. Lond. B Biol. Sci., 270, 313-321.

Hobbs H.H., Jr., 1989. An illustrated checklist of the american crayfishes (Decapoda: Astacidae, Cambaridae, and Parastacidae). Smithsonian Institution Press, Washington, D.C., 236 p.

Holdich D.M., 2002. Distribution of crayfish in Europe and some adjoining countries. Bull. Fr. Pêche Piscic., 367, 611-650.

Holdich D.M., Reynolds J.D., Souty-Grosset C. and Sibley P.J., 2009. A review of the ever increasing threat to European crayfish from non-indigenous crayfish species. Knowl. Manag. Aquat. Ecosyst., 394-395, 11.

Illés P., 2002. A jelzôrák (Pacifastacus leniusculus) előfordulása Magyarországon. Cinege - Vasi Madártani Tájékoztató, 7, 39 41.

Jones J.P.G., Rasamy J.R., Harvey A., Toon A., Oidtmann B., Randrianarison M.H., Raminosoa N. and Ravoahangimalala O.R., 2009. The perfect invader: a parthenogenic crayfish poses a new threat to Madagascar's freshwater biodiversity. Biol. Invasions, 11, 1475-1482.

Kaldre K., Meženin A., Paaver T. and Kawai T., 2016. A preliminary study on the tolerance of marble crayfish Procambarus fallax f. virginalis to low temperature in nordic climate. In: Kawai T., Faukles Z. and Scholtz G. (eds.), Freshwater Crayfish: A Global Overview. Boca Raton: CRC Press.

Kawai T., Scholtz G., Morioka S., Ramanamandimby F., Lukhaup C. and Hanamura Y., 2009. Parthenogenetic alien crayfish (Decapoda: Cambaridae) spreading in Madagascar. J. Crust. Biol., 29, 562-567.
Keller N.S., Pfeiffer M., Roessink I., Schulz R. and Schrimpf A., 2014. First evidence of crayfish plague agent in populations of the marbled crayfish (Procambarus fallax forma virginalis). Knowl. Manag. Aquat. Ecosyst., 414, 15.

Kouba A., Petrusek A. and Kozák P., 2014. Continental-wide distribution of crayfish species in Europe: update and maps. Knowl. Manag. Aquat. Ecosyst., 413, 05.

Kovács T., Juhász P. and Ambrus A., 2005. Adatok a Magyarországon élõ folyami rákok (Decapoda: Astacidae, Cambaridae) elterjedéséhez. Folia Historico Naturalia Musei Matraensis, 29, 8589.

Lipták B. and Vitázková B., 2015. Beautiful, but also potentially invasive. Ekológia (Bratislava), 34, 2, 155-162.

Lukhaup C., 2001. Procambarus sp. - Der Marmorkrebs. Aquaristik Aktuell, 7-8, 48-51.

Marten M., Werth C. and Marten D., 2004. Der Marmorkrebs (Cambaridae, Decapoda) in Deutschland - ein weiteres Neozoon im Einzugsgebiet des Rheins. Lauterbornia, 50, 17-23.

Martin P., Kohlmann K. and Scholtz G., 2007. The parthenogenetic Marmorkrebs (marbled crayfish) produces genetically uniform offspring. Naturwissenschaften, 94, 843-846.

Martin P., Dorn N.J., Kawai T., van der Heiden C. and Scholtz G., 2010. The enigmatic Marmorkrebs (marbled crayfish) is the parthenogenetic form of Procambarus fallax (Hagen, 1870). Contrib. Zool., 79, 107-118.

Martin P., Thonagel S. and Scholtz G., 2016. The parthenogenetic Marmorkrebs (Malacostraca: Decapoda: Cambaridae) is a triploid organism. J. Zoolog. Syst. Evol. Res., 54, 1, 13-21.

Moorhouse T.P., Poole A.E., Evans L.C., Bradley D.C. and Macdonald D.W., 2014. Intensive removal of signal crayfish (Pacifastacus leniusculus) from rivers increases numbers and taxon richness of macroinvertebrate species. Ecol. Evol., 4, 494-504.

Nyström P., 1999. Ecological impact of introduced and native crayfish on freshwater communities: European perspectives. In: Gherardi F. and Holdich D.M. (eds.), Crayfish in Europe as alien species. How to make the best of a bad situation? A.A. Balkema, Rotterdam, Brookfield.

Nyström P., 2002. Ecology. In: Holdich D.M. (ed.), Biology of freshwater crayfish. Blackwell Science, Oxford, 192-235.

Nyström P., Svensson O., Lardner B., Brönmark C. and Granéli W., 2001. The influence of multiple introduced predators on a littoral pond community. Ecology, 82, 1023-1039.

Oidtmann B., Cerenius L., Schmidt I., Hoffman R. and Söderhäll K., 1999. Crayfish plague epizootics in Germany - classification of two German isolates of the crayfish plague fungus by random amplification of polymorphic DNA. Dis. Aquat. Org., 35, 235-238.

Padisák J., 1999. A Balaton természettörténete. História, 21, 50-53.

Patoka J., Kalous L. and Kopecký O., 2014. Risk assessment of the crayfish pet trade based on data from the Czech Repulic. Biol. Invasions, 16(12), 2489-2494.

Ponyi J. (ed.), 2002. A Hévízi forrástó ökológiai állapota: szimpóziumi és kiegészítõ anyagok. Nereus, Hévíz.

Puky M. and Schád P., 2006. Orconectes limosus colonises new areas fast along the Danube in Hungary. Bull. Fr. Pêche Piscic., 380381, 919-926.

Puky M., Reynolds J.D. and Schád P., 2005. Native and alien Decapoda in Hungary: distribution, status, conservation importance. Bull. Fr. Pêche Piscic., 376-377, 553-568. 
Ramsar Convention Secretariat, 2015. The list of wetlands of international importance. Published 25 June 2015. Ramsar Convention Secretariat, Gland, Switzerland. http://www.ramsar.org

Reynolds J. and Souty-Grosset C., 2012. Management of Freshwater Biodiversity: Crayfish as Bioindicators. Cambridge University Press, New York.

Scholtz G., Braband A., Tolley L., Reiman A., Mittmann B., Lukhaup C., Steuerwald F. and Vogt G., 2003. Parthenogenesis in an outsider crayfish. Nature, 421, 806.

Schulz H., Gross H., Dümpelmann C. and Schulz R., 2009. Flusskrebse Deutschlands. In: Füreder L. (ed.), Flusskrebse: Biologie - Ökologie - Gefährdung. Veröffentlichungen des Naturmuseums Südtirol, Nr.6, Folio Verlag Bozen/Wien.

Seitz R., Vilpoux K., Hopp U., Harzsch S. and Maier G., 2005. Ontogeny of the Marmorkrebs (Marbled crayfish): a parthenogenetic crayfish with unknown origin and phylogenetic position. J. Exp. Zool., 303A, 393-405.

Specziár A., 2004. Life history pattern and feeding ecology of the introduced eastern mosquitofish, Gambusia holbrooki, in a thermal spa under temperate climate, of Lake Hévíz, Hungary. Hydrobiologia, 522, 249-260.

Szabó I., 1998. Termofitonok Hévíz és Keszthely meleg vizeiben. Kitaibelia, 3, 295-297.

Szabó I., 2002. Melegvízi növényfajok Hévíz és Keszthely vizeiben. Botanikai Közlemények, 89, 105-115.
Thompson J.D., Higgins D.G. and Gibson T.J., 1994. CLUSTAL W: improving the sensitivity of progressive multiple sequence alignment through sequence weighting, position-specific gap penalties and weight matrix choice. Nucleic Acids Res., 22, 46734680.

Thuránszky M. and Forró L., 1987. Data on the distribution of freshwater crayfish (Decapoda: Astacidae) in Hungary in the late 1950s. Misc. Zool. Hung., 4, 65-69.

van der Wal J.E.M., Dorenbosch M., Immers A.K., Vidal Forteza C., Geurts J.J.M., Peeters E.T.H.M., Koese B. and Bakker E.S., 2013. Invasive crayfish threaten the development of submerged macrophytes in lake restoration. PLoS One, 8, e78579.

Veselý L., Buric M. and Kouba A., 2015. Hardy exotics species in temperate zone: can "warm water" crayfish invaders establish regardless of low temperatures? Sci. Rep., 5, 16340.

Vogt G., Huber M., Thiemann M., van den Boogaart G., Schmitz O.J. and Schubart C.D., 2008. Production of different phenotypes from the same genotype in the same environment by developmental variation. J. Exp. Biol., 211, 510-523.

Vörös L., Mózes A. and Somogyi B., 2009. A five-year study of autotrophic winter picoplankton in Lake Balaton, Hungary. Aquat. Ecol., 43, 727-734.

Weiperth A., Csányi B., Gál B., György Á.I., Szalóky Z., Szekeres J., Tóth B. and Puky M., 2015. Exotic crayfish, fish and amphibian species in various water bodies in the region of Budapest. Pisces Hungarici, 9, 65-70.

Cite this article as: A. Lőkkös, T. Müller, K. Kovács, L. Várkonyi, A. Specziár, P. Martin, 2016. The alien, parthenogenetic marbled crayfish (Decapoda: Cambaridae) is entering Kis-Balaton (Hungary), one of Europe's most important wetland biotopes. Knowl. Manag. Aquat. Ecosyst., 417, 16. 